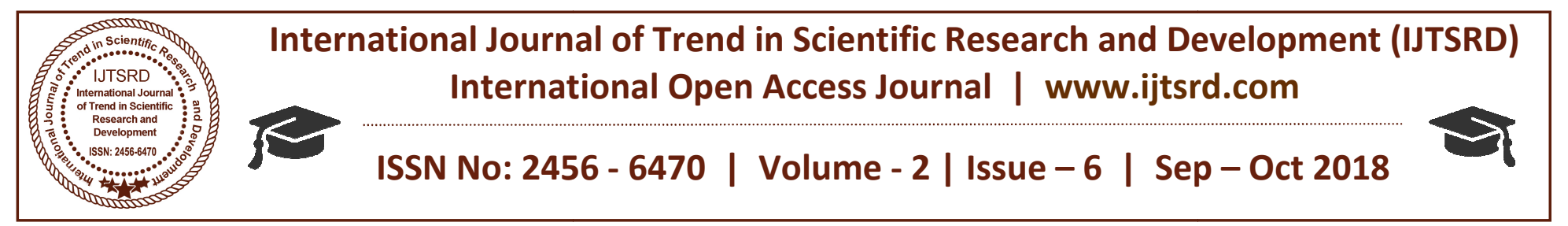

\title{
A Review of Netra Sharira
}

\author{
Majagaiyan Pratikshya ${ }^{1}$, Giri Jeevan Kumar ${ }^{2}$, H N Abhijith ${ }^{3}$ \\ ${ }^{1,2} \mathrm{PG}$ Scholar, ${ }^{3}$ Associate Professor \\ ${ }^{1,3}$ Department of Shalakya Tantra, ${ }^{2}$ Department of Rachana Sharir \\ Shree Dharmasthala Manjunatheswara College of Ayurveda and Hospital, Hassan, Karnataka, India
}

\section{ABSTRACT}

Netra is one of the jnanendriyas with high importance. Without eyes, the whole world will be dark and life will be meaningless. It is dominant of tejo mahabhuta. If Tejo mahabhuta does not enter in to dristi during garbhawa kala, than the child born will be having janmandhya. Nayana, Chakshu, Lochana, Drik, Darsanendriya are some of the synonyms of netra. There 5mandala, 5patala, 6sandhis, peshi, marma, sira in eyes. Different Acharyas have their own view in the utpatti of Netra during garbhawastha kala. Different parts of netra signify the panchabhautika composition.

\section{Keyword: Netra, Teja, Janmandhya, Panchabhautikata}

\section{INTRODUCTION}

NETRA SHAREERA: "Chakshurindriya", occupies the key position among the other Jnanendriyas.

\section{VYUTPATI / DERIVATION:}

The term Chakshu is derived from the root "chaksh" denoting Darshna (sight) and Karana (organ responsible for sight) according to Vachaspatya. According to Shabdakalpadruma the word "Chakshu" means Darshanendriya

NIRUKTI/ DEFINATION: According to Charaka, Chakshu is one among Pancha jnanendriyas, which is responsible for "Roopagrahana". Whereas Sushrutha defines Chakshu as a Buddindriya originating from "Rupatanmatra" performing visual perception with the dominance of "Tejomahabhutae".

\section{ETYMOLOGICAL DERIVATIONS:}

The scientific meanings of each of the synonyms as per Ayurvedic classics with their etymological derivations are as follows:

\section{Akshi:}

Source of reaching or seeing. Eye is more luminous than the other parts of the body. As + Kshi - means, which grasps objects

\section{Chakshu:}

Responsible for sight. Darshanendriya. Eye, vision, faculty to see, Lord Shiva, name of Maruta, Sage, Sun etc.

Chakshin - „Chakshate yena Chakshu.

Drishti : Source or tool with which one sees The word „,Drishti" has different meanings in Ayurvedic texts including Netra, Drishti Mandala, Netrakriya (vision), Ateendriya, Darshana etc

Netra: Which takes or drives one towards knowledge.

Nayana: One which drives objects towards its subject.

Lochana : The tool with which one sees. According to Amarkosha, this has the capacity to see.

\section{NETRA UTPATI/ \\ EMBRYOLOGICAL \\ DEVELOPMENT:}

As per Charaka the development of the Indriyas begin during the third month of Garbhavakranti. Kashyapa opines that eye is the first organ to develop in the fetus. But Punarvasu Atreya declares that all the sense organs develop simultaneously. As per Sushrutha the subtle form of all the Indriyas are present during the formation of Garbha . Ekadasha indriyas including Chakshurindriya are derived from the combination of Vaikarika Ahankara with the Sathwika Ahankara. All the indriyas become explicit during the third month. Vagbhata attributes development of Indriyas to Kapha and Raktavaha Srotas. He details the embryological 
aspect of each part of the eye, for example Shukla Mandala is developed from Kapha and it is said to be a Pitraja Bhava, Krishna Mandala from Rakta and a Matraja Bhava. Both these factors collectively form Dristhti Mandala. Sushrutha describes the role of Panchamahabhuta in the development of various parts of the eyes. The muscular portion is derived from Prithvi, Rakta from Agni, Krishnabhaga from Vata, Shwetabhaga from Jala and Ashrumarga from Akashamahabhutas. He described the role of Tridosha in determining the colour of the eye. Like Teja in association with Rakta Dhatu results in Raktakshi (reddish eye) the same Tejas in association with Pitta forms Pingakshi (dark brown eyes) and with Kapha causes Shuklaksha (pale eye), If Tejo Mahabhoota does not reach to Drishti part then child is born congenitally blind and Vata in association with Tejo Mahabhoota causes Vikrutakshya. Sushrutha explains that, Netra is the Prasada bhaga of „Majja". Majja Dhatu is placed above Akshi. Any Sara/asara or Vriddhi/Kshaya of Majja Dhatu affects the Chakshurindriya. Hence Majja is Maha Netra. Therefore in case of Majja Vriddi the Gauravata in Akshi and also Bhrama as well as Tamadarshana can be seen in Majja Kshaya. Hence various factors responsible for the development of different parts of the eye and colour the eye, thus relates to the constitutional variations, which are of high scientific value to understand the state of Dosha predominance in very early phase of development. Both Charaka and Sushruta consider Indriyas as Atmaja Bhava. The clearness of senses (Indriya Prasada), however is attributed by Satmyaja Bhava. According to Vaghbhata, the respective agnis of mahabhutas will digest the channels of kapha and rakta to develop sense organs. The essence of Kaphavaha shrotas forms Shukla mandala and the essence of Raktavaha shrotas is developed as krishna mandala. These two are pitrija and matrija bhavas, respectively. Both of them collectively produce Dristi mandala.

\section{PARYAYA/SYNONYMS:}

Shivashakti, Strimurti, Trikala, Linga, Mahajyothi (Netraprakashika), Lochana, Nayana, Darshana, Akshini, Drik, Drishti (Parishadya Shabdartha Vijnana).

\section{PANCHABHAUTIKA COMPOSITION:}

Netra is composed of all the five Mahabhutas i.e,

1. Mamsa-Prithvi

2. Rakta- Agni

3. Krishna mandala- Vayu
4. Shewta mandala- Jala

5. Ashrumarga- Akasha

NETRA -SHAREERA: Realizing the importance of the eye, Sushruta has described the Anatomy of this organ in most elaborated and practical way while discussing various anatomical components in terms of their size, shape, and relation as is visible in a person.

Situation: Head is the supreme part of the human body (uttamanga), when compared to all other parts. It is the site of life for living beings. All the senses are situated in and supported by the head. Two eye orbits are situated in the head, which are the shelter of two Netras, but one Chakshurindriya. These Netraguhas are the two among the nine external openings of the Shiraha.

Shape: In Sushruta Samhita Uttartantra, Acharya has described Netra as Suvrittam, Gostanakaram and Nayana Budbudam, which denotes the shape and consistency of the Netra.

A. Suvrittam: By the word Suvrittam means that eye is spherical from all sides.

B. Gostanakaram: By the word we mean that eye is shaped like that teat of the cow i.e. oblong shaped or oval shaped. Eyeball seen along with extra ocular muscles and optic nerve is very much similar to Cowes steat.

C. Nayana Budbudam: It means like a bubble floating on the water i.e. round in shape and soft in consistency and glossy / glistening in character, this term suggestive of external appearance of the eye in the eye orbit.

\section{DIMENSIONS OF NETRA:}

The measurements of the eyeball were described by Sushruta in terms of „Anguli" like any other organ but, Anguli in context to measurement of Netra is equal to Swangushthodara i.e. one's own thumb, which has been supported and clearly written by the commentator Dalhana. And he had given two dimensions - 2 Angulas Bahulya and 2 1/2 Angulas Sarvata. According to some scholars, the word „Bahulya" means anteroposterior diameter or thickness of the eyeball and it is 2 Angulas. As per their view, the word ,Sarvatah" can be considred as the side-toside measurement i.e. circumference of the eyeball; and it is $2 \frac{1}{2}$ Angulas. But the exact measurement of 2 $1 / 2$ Angulas is better applicable to the side to side distance of the eye. [I.e. the distance from inner canthus to outer canthus]. According to Dalhana, the 


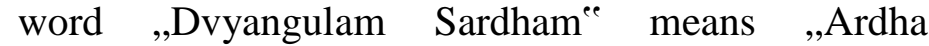
Triteeyangula ${ }^{e e}$. This was commented by some scholars as $3 \frac{1}{2}$ Angula, and they apply it as the circumference of the eyeball.

\section{ANATOMICAL PARTS OF THE NETRA:}

The anatomical parts of the eye were described by Sushruta as 5Mandalas, 6Sandhis and 6Patalas. The same division was adopted by Vagbhatta, Madhavakara and Bhavamishra also.

MANDALA: The word Mandala is made from root „Mad" + „Klach" pratyaya i.e. which covering circular areas or concentric circles. The five Mandalas of the eye are:

1. Pakshma Mandala: This is the first and outermost Mandala of the eye formed by the Pakshma or the eyelashes. "Pakshmani Vartmaromani". They is situated in the lid margins called pakshmashaya or pakshma sadana. Paksma is a form of Kesa and considered as upadhatu of majja.

2. Vartma Mandala: Upper and Lower eyelids jointly form a circle in front of the eyeball, which is termed as Vartma Mandala. It is also known as Aksi Kosha considering its protective function. The external muscles of the eye lid are the part of mandal pesi. There is one snayu which is of prithu type. There is tarunasthy in the eye lids. The two eye lids meet in two sandhis called as Kaninika and Apanga. The movement of the vartma is regulated by Nimesha Unmesha Shira.Vartma consits of two bahya patalas. Vartma mandala is muscular organ consisting of prithivi maha bhuta dominanace and sthanik dosha is kapha. Nimesha and Unmesha karma is the major function of vartma mandala which is carried out by Vyana vayu.

3. Shukla Mandala: This portion appears as whitish and therefore known as Shukla Mandala. The Shukla Mandala can be correlated to the scleral part of the outer fibrous coat of the eyeball covered with conjunctiva. Shukla mandala forms sandhi with neighbouring mandalas as follows peripherally vartma shukla sandhi, medially kaninika sandhi, laterally Apanga sandhi. It is dominated by kapha due to the presence of jala mahabuta.The sthira, snigdha and guru properties of kapha provides shape and stability to the eye ball.

4. Krishna Mandala: The size of this Mandala is $1 / 3$ rd of the whole Netra. This Mandala can be compared with the cornea; and appears as blackish because of the iris underneath even though it is transparent. "Vatat Krishnam". Krishna mandala has the predominance of vata.

5. Drishti Mandala: Last and innermost circular structure of the Netra encloses Drishti in it and hence named Drishti Mandala. Measurement of Mandala is $1 / 7$ th of Krishna Mandala in the opinion of Videha and Dalhana. Sushruta also expresses same thoughts. According to Astanga Sangraha it is said to be equal to 1/9th part of the "krishna mandala". A gap of 4 angula exists between the centre portion of two dristi. The shape of dristi mandala is like masur seed..On the contrary Shushrut also explains dristi mandal as $1 / 9$ th of krishna mandala to the refernce of $1 / 7 \mathrm{th}$. It can be compared to Pupils or the orra serrata region.

\section{SANDHIS:}

Sandhis are the "Junctional Areas" between two Mandalas. The Sandhis are 6 in number. They are

1. Pakshma - Vartma gata Sandhi: The union line of Pakshma Mandala and Vartma Mandala is called as the Pakshma Vartmagata Sandhi and it is considered as the lid margin.

2. Vartma - Shukla gata Sandhi: The union line of Vartma and Shukla Mandala is called as Vartma Shuklagata Sandhi. Fornix of the eyeball where the palpebral conjunctiva is reflected on to the bulbar conjunctiva seems to be Vartma Shuklagata Sandhi.

3. Shukla - Krishna gata Sandhi: The circular line joining between Shukla Mandala and Krishna Mandala is called as Shukla Krishnagata Sandhi. This junctional area can be considered as the sclero - corneal junction i.e. Limbus.

4. Krishna - Drishti gata Sandhi: The union line of Krishna and Drishti Mandala is called as Krishna - Drishtigata Sandhi. By considering iris part in Krishna Mandala, this Sandhi can be explained and the central free margin of the iris, which rests on the anterior capsule of the lens, can be considered as the Krishna Drishtigata Sandhi. Otherwise there is no apparent union line between the cornea and pupil.

5. Kaneenika Sandhi: Dalhana describes this Sandhi and it can be considered as the inner or nasal canthus of the eye.

6. Apanga Sandhi: Dalhana describes Apanga Sandhi and it can be considered as the outer canthus Of the eye.It is one of the marma point. 
PATALAS: Patala is one of the structures told by Sushruta in Netra Shareera. Various authors have described and interpreted the concept of Patalas in their own way and yet no consensus has reached upon among them on this subject. V.S. Apte, in his Sanskrit - English dictionary describes the meaning of Patala as a film or coating over the eyes. According to Monier Williams, it can be considered as a layer of the eyeball.

Etymology: Pat + "Klach" pratyaya- Which means a layer, veil, covering chest, membrane especially of the eyes, a film over the eyes. So it can be considered as the layers of the eyeball ${ }^{35}$. There are 6 Patalas in the eyeball - 2 Vartma Patalas and 4 Akshi Patalas. The pathogenesis of Drishtigata Rogas, especially Timira has been described in terms of involvement of successive Patalas. The prognosis of the disease also depends upon the involvement of respective Patala. Sushruta considers different Akshi Patalas and their constituting factors are as follows ${ }^{36}$.

The outermost first patala is supported by Tejas \& Jala; the second one consists of Mamsa, the third Patala is described as "Medoashrita ${ }^{\text {ee }}$ and the fourth Patala is „Asthyashrita"e. Their thickness is equal to one-fifth of the Drishti ${ }^{36}$. Dalhana has described thefirst or outermost Patala as "Tejojalashrita". According to Dalhana, the word Teja means Alochaka Pitta and so Siragata Rakta can be taken as Teja. Jala, according to him implies Rasa Dhatu. So it can be considered that the first Patala is the Ashraya for Rasa and Rakta Dhatus.

According to some scholars, the Prathama Patalas can be taken as Cornea and Aqueous humour; as they are the seat of Tejas and Jala. The 2nd Patalas, which is Mamsashrita, can be taken as Iris and Ciliary body. Both iris and ciliary body are mesodermal in origin and contain muscles tissue. The 3rd Patala or Medoashrita Patala can be taken as Lens \& Vitreous humour, as lens is explained as 3rd patala for its position next to uvea $\&$ vitreous is a jelly like structure which resembles medas (fat). The 4th Patala or Asthyashrita Patala can be taken as Retina, as it is the seat for Linganasha. Their opinion can be summarized as follows:

1st Patala Cornea \& Aqueous humour, 2nd Patala Iris and Ciliary body, $3^{\text {rd }}$ Patala Lens $\&$ Vitreous humour, 4th Patala Retina.
RELATIVE POSITIONS OF EACH PATALA: Only one clinical feature of the Prathama patala has been described by Acharya Vagbhatta is blurred/indistinct vision, which becomes clear sometimes without any reason. As the disease vitiate the superficial Dhatus only, the prognosis is good. Prathama Patala, among the four Akshi Patalas, is known as Bahya or outer; this means that the other three are relatively inner to the former.

According to Sushruta, the disease Timira vitiates the first Patala, followed by second, third and fourth Patalas. Therefore the first Patala is considered as the outermost and the fourth Patala is considered as the innermost Patala. But the commentary given by Dalhana did not correspond to it and he has reversed the relative position of each Patala. Dalhana Describes „Kalakasthi Ashrita" Patala as the first Patala and considers it as innermost. According to him, the second Patala is Medoashrita, third Patala is Mamsashrita and the fourth Patala is Tejojalashrita. This description can be considered as a misinterpretation from Dalhana. Actually he had misunderstood the word "Abhyantara" given by Sushruta in the description of Prathama Patalagata Timira and considered the first Patala as the Abhyantara (innermost) Patala. According to some other scholars, the Patalas can be taken as the layers of the cornea. They quote Vagbhatta to justify their opinion. While describing the prognosis of the disease „Kshata Shuklae, it has been said that the disease is Kricchra Sadhya when it occurs in the first Patala. There the word ,Twak ${ }^{e e}$ is used for Patala. When the disease involves the second Patala, it becomes Yapya and Asadhya when it involves the third Patala. As the disease „Kshata Shuklae is limited to the cornea only, these Patalas can be taken as successive layers of the cornea. There is one other view in which the Patalas are taken as different layers of the lens itself. To justify this, they argue that the lens is the only structure where the changes of the diseases Timira, Kacha and Linganasha are taking place. They consider the anterior lens capsule as the first Patala and nucleus as the fourth Patala.

According to some other views, the Patalas can be taken as different layers of retina. There is third Patala involvement for the diseases Pittavidagdha Drishti and Kaphavidagdha Drishti. These are the diseases where patients complain of day blindness and night blindness respectively. As these diseases occur due to degeneration of rods and cones. The Patalas can be 
taken as different layers of retina. But, by taking the retina as Patalas, we cannot explain the clinical entity Timira. However, there is another view that, all these patalas are seated in Dristi mandala. Their thickness is one fifth of Dristi mandal. This will lead to concept of dividing Dristi mandala in to four distinct layers; each layers of retina representing patalas.

Tejojalashrita Patala: Pigment cell layer, rods and cones layer.

Mamsaashrita Patala: Outer and Inner nuclear layer and plexi form layer.

Medoashrita Patala: Layer of ganglion cells. Asthyashrita Patala: Layer of optic nerve fibres.

To conclude, we can say that Patalas were described by Ancient Acharyas in order to show the severity of the diseases when they involve deeper tissues and no single structure can be correlated with particular Patala exactly probably the used Patala is to be taken for different structures in different contexts.

\section{CONCEPT OF DRISHTI}

As Timira is one among the Drishti gata Rogas, it is quiet essential to know more about Drishti.

\section{Etymology:}

Drish + ,Ktin Karane" pratyaya-Meaning the tools to see.

The concept of Drishti by Acharya Sushruta is little different and all the description of Drishti given by him points to the pupil ${ }^{37}$ i.e.

$>$ Masura dala matra [size of a Masura dala]

$>$ Prasada of Panchamahaboota

$>$ Covered by the external Patala

$>$ Sparkle like glow worm (Khadyotavisfulingabha)

$>$ Constantly irrigated by the cold aqueous

$>$ Shape resembles a hole (Vivirakritim)

$>$ Benefited with cold things

Sushruta has given the measurement of Drishti as 1/7th of Krishna Mandala, in Uttartantra. But in Sutrasthana, it is described as 1/9th of Taraka. Here the meaning of Taraka was given as Krishna Mandala. So different measurements for the same structure given by the same author points that Drishti is a constricting and dilating structure and this also points to the pupil. So 1/7th of Krishna Mandala is the measurement when the iris is dilated, while 1/9th of Krishna Mandala is the measurement when the iris is constricted $^{38}$.
All these descriptions prove that the Drishti was considered as pupil by ancient Acharyas. The anatomical description of Drishti is present only in Sushruta Samhita. But now it is very clear that the word Drishti is a broad sense having a wide range of meaning. If pupil alone will be taken as Drishti, then the Drishtighna Rogas should be confined only to the pupil. But it is clear that none of the Drishtigata Rogas are confined to the pupil. Instead, the Drishtigata Rogas are the diseases, where the structural lesion is present somewhere in the refractive medium or retina. In some of the Drishtigata Rogas, higher centers like optic nerve and visual cortex are also been involved. So it is better to take these all in toto as the Drishti. Drishti in simple sense means vision. All the anatomical structures through which light passes to reach the retina including the optical zone of cornea, aqueous humour, lens, vitreous humour and retina can be included in the Drishti.

Akshi Bandhana: All the internal parts of the eye are properly alligned together by akshi bandana.The component are sira, kandara, meda and kapha. sleshma is the binding material in all such joints. In addition to properly holding of the eye parts, akshi bandhana will also fix the patalas properly. SiraDhamani in first patala, Kandara in second patala, Medas in third patala, Kalakasthy is the black coloured bone. The word Kalakasya ca is replaced by Krishna Bandhane in manuscript according to Dalhana. According to Sasilekha commentary of Acharya Indu, The first patala consists of Sira guna, the qualities of tejas and jala are also seen here. The second patala has Kandara guna which is derivative of mamsa dhatu. The third patala has meda guna; exact visual perception takes place in this patala as dristi is seated in medas, kalakasthy remains outside medas. Kapha supports all of them. These have links to all body parts and tissue from sole of the feet to centre of the heart. Dipika commentary has identified four mandalas in dristi as Rasa raktasraya, Mamsa raktasraya, Medasamshraya and Kamala sthitha.

Marma: There are three marmas releated to eye i.e Apanga, Aavarta and Shringataka. Apanga is situated in the lateral end of the lower side of the eye .It is a shira marma and half angula in size. Avarta marma is a sandhi marma lying above the eyebrows .It is also of half angula size. The damage to these two will result in either blindness or visual impairment. Shringataka is a junctional area of the channels of nutrition of 
sense organs like nose, ear, eye and tongue. It is situated between two eye brows. It is a sira marma of four angula sizes. Any trauma to these points will be fatal.

Sira: There are 38 sira to carry doshas. Among them vata is carried in eight siras, pitta, rakta and kapha are carried in ten siras each. Two of them take part in lid movement. A total number of 56 siras one present in both eyes. Among them two each are responsible for lid movement and one in apanga sandhi. These six siras should not be opened during sira vyadha.

Dhamani: There are rupa vaha dhamani to transmit visual percerption and asruvaha dhamanis for the flow of tears one in each eye.

Snyau, Peshi:There is a snayu of prithu type in the eyes. One pesi is situated in each eye, which circular (mandala) in shape.

\section{Disscussion:}

Netra is one of the jnanendriyas with high importance. Without eyes the whole world is dark and life is meaningless. Netra, Nayana, Lochana, Drik, Chakshu, Darsendriya are some of the synonyms of netra. Chakshu it is derieved from "Chaksh" root which means darshana or sight. Netra performs both roopa grahana and buddhigrahana as it is the seat of Aalochaka pitta. It is predominant of Tejo mahabhutas so there is always fear of kapha to eye. When teja doesnot enter to drusti during garbhawakala, Janmandhya occurs. Regarding the utpatti of netra various Acharyas have different views .Some say during $3^{\text {rd }}$ month of gestation, some say the first organ to develop and some say the subtle of all indriyas will be present during formation of garbha. As whole world is made of mahabhutas, netra and its various parts signify their panchabhautika composition. Netra is the Prasada bhaga of majja dhatu hence majja khasaya and vruddhi shows impact on netra. There are
2 netra golaka situated in netraguhas . The shape of netra is like gostana, suvritta, or budbuda. Mandala (5), Patala(5) and sandhi(6) are the anatomical parts of eye. These are the parts where dosa get localized and produce various types of netra rogas. When dosa invade deeper and deeper patala, timira, Kacha and Linganasa are produced. Netra also consists of Akshi bandhana, sira, pesi, dhamani, marma, snayu as accessory parts. Thus, whole of Patala.

Mandala, Sandhi, Akshi bandhana, sira, pesi, dhamani, marma, snayu completes the netra sharira.

\section{Conclusion:}

For the proper diagnosis of netra rogas, the detailed study of netra sharira is necessary. Vitiated doshas when get accumulated in netra produce 76 types of netra rogas manifested as Sandhigata rogas, Vartmagata rogas, Shuklagata rogas, Krishnagata rogas, Sarvagata rogas and Drusti gata rogas.

\section{References:}

1. Shastri Ambika Dutta. Susruta Samhita of Maharshi Susruta. Varanasi: Chaukhamba Sanskrit Sansthan; 2017.

2. Shukla Vidhyadhara Tripathi Ravi Dutta. Caraka Samhita of Agnivesa: New Delhi: Chaukambha Sanskrit Pratishthana; 2012.

3. Murthy Srikantha K R. Astanga Samgraha of Vaghbhata: Varanasi: Chaukhamba Orientalia; 2012.

4. Murthy Srikantha K R. Illustrated Susruta Samhita: Varanasi: Chaukhamba Orientalia; 2012.

5. Shankar Udaya. Text Book of Shalakya Tantra(Illustrated): Chaukhamba Visvabharathi; 2012.

6. Biswal Adikanda Routray Rasmita. A Text Book of Shalakya Tantra. New Delhi: Chaukhamba Publications; 2015. 